\title{
Evaluation of WRF-Chem Model Forecasts of a Prolonged Saharan Dust Episode over the Eastern Alps
}

\author{
Kathrin Baumann-Stanzer ${ }^{1 *}$, Marion Greilinger ${ }^{1}$, Anne Kasper-Giebl ${ }^{2}$, Claudia Flandorfer ${ }^{1}$, \\ Alexander Hieden ${ }^{1}$, Christoph Lotteraner ${ }^{1}$, Martin Ortner ${ }^{3}$, Johannes Vergeiner ${ }^{4}$, \\ Gerhard Schauer ${ }^{5}$, Martin Piringer ${ }^{1}$
}

${ }^{1}$ Central Institute for Meteorology and Geodynamics (ZAMG), 1190 Vienna, Austria

${ }^{2}$ Institute of Chemical Technologies and Analytics, Vienna University of Technology, 1060 Vienna, Austria

${ }^{3}$ ZAMG Customer Service Carinthia, 9020 Klagenfurt, Austria

${ }^{4}$ ZAMG Customer Service Tyrol and Vorarlberg, 6020 Innsbruck, Austria

${ }^{5}$ ZAMG Customer Service Salzburg and Upper Austria, 5020 Salzburg, Austria

\begin{abstract}
Transported Saharan dust creates a substantial natural background to particulate matter concentrations in Central Europe. The contributions by Saharan dust are especially detectable at Alpine mountain sites, where many other sources have little impact. The ability of a chemical weather forecasting model to simulate dust transport is of vital interest, as serious health effects due to this phenomenon, similar in scale to those resulting from nuclear or industrial accidents, wildfires, pollen, etc., may require countermeasures. Thus, we investigate whether the WRF-Chem model set-up, which is run operationally for air quality forecasts in Austria, can accurately predict the transport of the Saharan dust cloud towards Central Europe in April 2016. WRF-Chem simulations with and without desert dust emissions reveal that whenever PM concentrations were high during the three periods of this event, $60-70 \%$ of the dust arriving at the Eastern Alps originated in the desert. The measurements and model results deliver a detailed picture of the course of this extraordinary dust event, with successive peaks over the Eastern Alpine region. Using this long-lasting Saharan dust event as an example, a structured step-wise approach is proposed to investigate peak dust episodes based on data analysis of representative background sites, source area analysis by means of Lagrangian dispersion modelling, and coupled meteorological and chemical modelling.
\end{abstract}

Keywords: Saharan dust; Long-range transport; WRF-Chem model; FLEXPART model; Source-receptor sensitivity; Ceilometer.

\section{INTRODUCTION}

Almost $2 \times 10^{9}$ tons of dust are emitted every year from arid and semi-arid areas (Monks et al., 2009). The largest dust source region in the world is North Africa. Ginoux et al. (2012) estimate, based on MODIS dust optical depth images combined with land use information, that North Africa accounts for $55 \%$ of global dust emissions with only $8 \%$ of anthropogenic origin. The main potential source areas of African dust are Western Sahara and Morocco, Algeria and Tunisia (Salvador et al., 2014). Most of the Saharan dust, about $60 \%$, is transported westward across the Atlantic and to the Caribbean (Prospero and Mayol-Bracero, 2013), but about $10 \%$ of the desert dust which is entrained into the

\footnotetext{
* Corresponding author.

Tel.: 0043136026 2402; Fax: 004313602674

E-mail address: k.baumann-stanzer@zamg.ac.at
}

free atmosphere is transported towards the Mediterranean Sea and Europe depending on the prevailing large-scale pressure fields and flow patterns (Schepanski et al., 2016). According to Pey et al. (2013), African dust outbreaks are more frequent in southern sites across the Mediterranean, from 30 to $37 \%$ of the annual days, whereas they occur less than $20 \%$ of the time in Central Europe. Nevertheless, the identification and quantification of dust transport from desert areas to Europe is relevant as these events can be classified as "natural events" in the official reporting of air quality measurements to the European Union. For this purpose, Alpine observatories render especially valuable data on these dust clouds as these background measurements are less influenced by other sources such as traffic, industry and domestic burning (e.g., De Angelis and Gaudichet, 1991; Coen et al., 2004).

Besides the analysis of particle matter measurements at mountain tops in the Eastern Alps, the source regions of the dust clouds and the pathways to the Alpine ridge are of interest to scientists as well as to authorities planning 
countermeasures. Sodemann et al. (2006) conclude from ice core data and trajectory analyses that different transport pathways rather than different source areas lead to major differences in the chemical signature of the deposited dust. The transport patterns of dust from the Saharan desert to the Alps can vary substantially from case to case or even within phases of a single event lasting for several days. In many dust transport studies, back-trajectories (Ansmann et al., 2003; Querol et al., 2009; Schauer et al., 2016) or ensembles of trajectories (Sodemann et al., 2006; Salvador et al., 2014) are used. Birmili et al. (2010) apply the Lagrangian model FLEXPART in backward mode to investigate transatlantic aerosol transport to the Alps. Column-integrated source-receptor sensitivity (SRS) fields are used to reveal the overall pathway of the air. The SRS fields in the lowest $100 \mathrm{~m}$ AGL are interpreted by Birmili et al. (2010) in terms of a "footprint" relationship indicating the dominant source regions. In this study, the same backward modelling approach is used to clarify whether the dominant source regions are situated in the Saharan desert during the episode under investigation.

Flaounas et al. (2016), Rizza et al. (2017) and Nabavi et al. (2017) present improved source function schemes to estimate dust emissions from arid areas for the on-line coupled chemical and meteorological forecast model WRF-Chem.

Remote sensing data from satellites (e.g., Alpert and Ganor, 2001; Monks et al., 2009; Ginoux et al., 2012; Todd and Cavazos-Guerra, 2016) and lidar profiles (Ansmann et al., 2003; Salvador et al., 2011) are used to monitor the release and transport of dust plumes. In this study, ceilometers are used to help investigate whether a dust plume is primarily advected or is mixed upwards from ground-level sources to the mountain tops by vertical mixing. Ceilometers are aerosol lidars which are operated since decades at airports to detect the cloud base height. The software of modern ceilometers is able to analyse the first few kilometres above ground for the existence of so-called "aerosol layer heights" which mark transitions between layers of different aerosol content (Lotteraner and Piringer, 2016).

Based on the measurements at three mountain top sites in the Eastern Alps, combined with aerosol profiles observed with ceilometers and the source region analysis, the evolution of a Saharan dust event in April 2016 is elaborated and the capability of WRF-Chem to forecast this event is demonstrated.

The Saharan dust cloud reached Central Europe on March 31, 2016, and remained there for about 10 days. Enhanced levels of $\mathrm{PM}_{10}$ concentrations were most obvious on mountain stations as well as at many stations of the routine air quality monitoring network across Austria. The proof that the enhanced $\mathrm{PM}_{10}$ concentrations originated from the Sahara is based on observations and models. The novel aspect of this research is the step-wise analysis of in-situ as well as remote sensing measurements and the application of forward and backward modelling in order to get a deeper understanding of the evolution of a dust event.

All in all, this study reveals how measurements and analysis tools can be used to investigate exceptional air pollution events caused by long-range transport.

\section{METHODS}

\section{Site Description}

Particulate matter (PM) measurements at three Austrian mountain stations, Feuerkogel, Sonnblick and Dobratsch, situated in a north to south transect across the Alps, are used to evaluate the WRF-Chem model performance. The global GAW station Sonnblick is located at the main Alpine ridge, while Feuerkogel and Dobratsch are situated further north and south, respectively. Three ceilometers located in Salzburg, Radstadt and Nötsch were used to measure the aerosol structure and to better interpret observed PM concentrations. Fig. 1 displays the location of the sites.

The continuously manned Sonnblick Observatory (SBO) is one of 31 global stations of the Global Atmospheric Watch Program (GAW), situated at the summit of Mt. Sonnblick at $3.106 \mathrm{~m}$ a.s.1. in the Austrian Alps $\left(12^{\circ} 57^{\prime} \mathrm{E}\right.$, $\left.47^{\circ} 03^{\prime} \mathrm{N}\right)$, within the core zone of Hohe Tauern National Park. The peak of Mt. Sonnblick is surrounded by large glacier fields and located approx. $1000 \mathrm{~m}$ above the tree line.

The continuously manned meteorological station Villacher Alpe is operated by ZAMG on top of Mt. Dobratsch $\left(13^{\circ} 40^{\prime} \mathrm{E}, 46^{\circ} 36^{\prime} \mathrm{N}\right)$ in $2.117 \mathrm{~m}$ a.s.l. since 1994 . The station was additionally equipped with particle matter measurements in October 2015.

The continuously manned meteorological station on top of Feuerkogel $\left(13^{\circ} 43^{\prime} \mathrm{E}, 47^{\circ} 49^{\prime} \mathrm{N}\right)$ at $1.618 \mathrm{~m}$ a.s.l. was put into operation in 1992 and is additionally equipped with particle matter measurements since January 2016.

\section{Particulate Matter Measurements}

The size fraction $\mathrm{PM}_{10}$ (particulate matter $\leq 10 \mu \mathrm{m}$ aerodynamic diameter) is determined with a Grimm EDM 180 Dust Monitor at the top of Feuerkogel and with a SHARP-Monitor (Model 5030, Thermo Scientific) at the top of Dobratsch.

At the Sonnblick Observatory, particulate matter is sampled with a SHARP-Monitor (Model 5030, Thermo Scientific) via a heated whole air inlet, which is recommended for high alpine mountain sites according to the GAW guidelines (WMO/GAW Report No. 153, 2003). The upper cut-off size of the inlet is $20 \mu \mathrm{m}$ at a wind speed of $20 \mathrm{~m} \mathrm{~s}^{-1}$, but for particles $>1 \mu \mathrm{m}$, losses will occur (Schauer et al., 2016). Thus, concentrations determined during the transport of mineral dust have to be regarded as a lower limit to actual conditions at the site. On the other hand, no local sources of PM with particle diameters larger than $10 \mu \mathrm{m}$ can be expected at the site as the soil is rock or ice/snow covered. Transport of PM with particle diameters larger than $10 \mu \mathrm{m}$ to the top of Sonnblick from sources at the valley bottom is unlikely as these particles are removed at lower levels due to their deposition velocity. Thus the PM mass concentrations at Sonnblick are compared with $\mathrm{PM}_{10}$ concentrations from model output or other sites. Furthermore, PM measurements at Sonnblick comprise the total number concentration using a condensation particle 


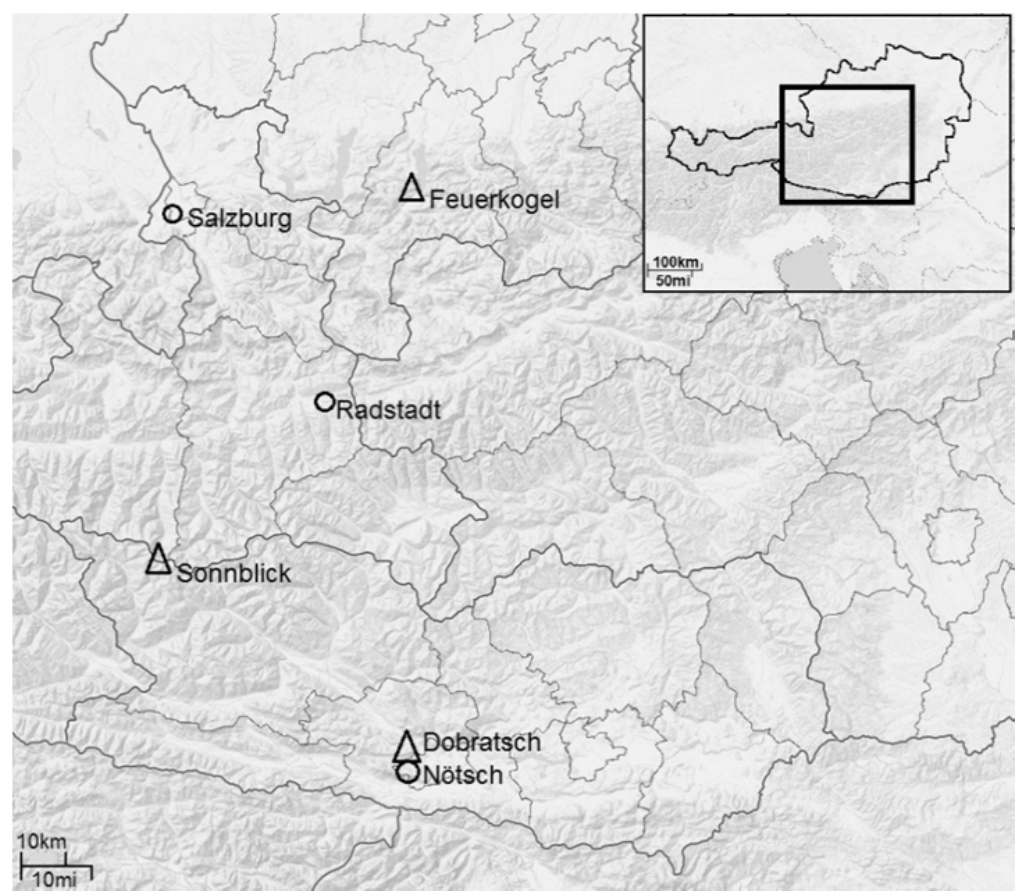

Fig. 1. Detailed map of Eastern Alps in Austria with mountain top air quality stations (triangles) and meteorological stations and ceilometer CL51 sites (circles).

counter (CPC 3022A, TSI Inc.), and particle size distribution is measured in the size range between 0.3 and $>2.5 \mu \mathrm{m}$ via an optical particle counter (TCC-3, Klotz). Optical aerosol properties, especially the single-scattering albedo (SSA) and the absorption coefficient (ABS), are measured using a 3-wavelength polar nephelometer (Aurora 4000, Ecotech) and a 7-wavelength Aethalometer (AE33, Magee Scientific). All measurements are reported as 30-min averages and aerosol concentrations given are calculated for $273 \mathrm{~K}$ and 1013 mbar. The wavelength dependence of the SSA and the ABS are investigated. The wavelength $(\lambda)$ dependence of both parameters is fitted with a power-law dependence to obtain the respective exponents, $\alpha_{-} S S A$ and $\alpha \_A B S$. The equation is shown exemplarily for the exponent $\alpha \_S S A$ :

$S S A=b \_S S A \times \lambda^{-\alpha} \_S S A$

The wavelength dependence of the SSA is used to identify long-range transport of mineral dust, e.g., originating from the Sahara (Coen et al., 2003).

In order to detect dependencies of pollutant distributions on flow patterns, daily mean $\mathrm{PM}_{10}$ concentrations at Sonnblick, Dobratsch and Feuerkogel are analysed according to the large-scale flow between January 14, 2016, and December 31, 2016, based on the operational synoptic weather circulation classification implemented at the national weather service for Austria, ZAMG (Classification of Atmospheric Circulation Patterns representative for the Alpine area model output data), in Fig. 2. Daily mean PM concentrations are calculated by averaging time-series of half hourly concentration values. A minimum of $75 \%$ of data availability per day is required to render a valid daily average.

\section{Ceilometer Measurements}

The ceilometer CL51 employs a diode laser lidar technology. Laser pulses with a wavelength of $910 \pm 10 \mathrm{~nm}$ are sent out in a vertical or near-vertical direction. The measurement range of the instrument extends from approximately $50 \mathrm{~m}$ above the ceilometer site, where a sufficient overlap of emitted and backscattered laser signals is given (Wagner and Schäfer, 2015), up to $15 \mathrm{~km}$ above ground.

The base heights of up to 3 cloud layers as well as up to 3 aerosol-layer heights are detected from the observed backscatter profiles by applying the so-called "gradient method" described in Emeis et al. (2007). An improved algorithm to determine the mixing height from ceilometer aerosol layer heights is described in Lotteraner and Piringer (2016).

\section{Source Region Analysis}

The Lagrangian particle model FLEXPART (Stohl et al., 2002), a stochastic particle dispersion model with turbulence and convection parameterisations, is used to identify the source regions of the air arriving at the mountain top sites. Lagrangian particle models usually release a high number of particles at defined source locations, compute their forward trajectories according to the three-dimensional wind fields with regard to all linear processes influencing the mass attached to these particles, i.e., advection, diffusion, convective mixing, dry and wet deposition. Non-linear chemical reactions cannot be simulated with this modelling approach. By reversing the sign of the advection, the trajectories can easily be calculated backward, starting in this case from the receptor points, e.g., measuring stations. This methodology, described in detail by Seibert and Frank (2004), 


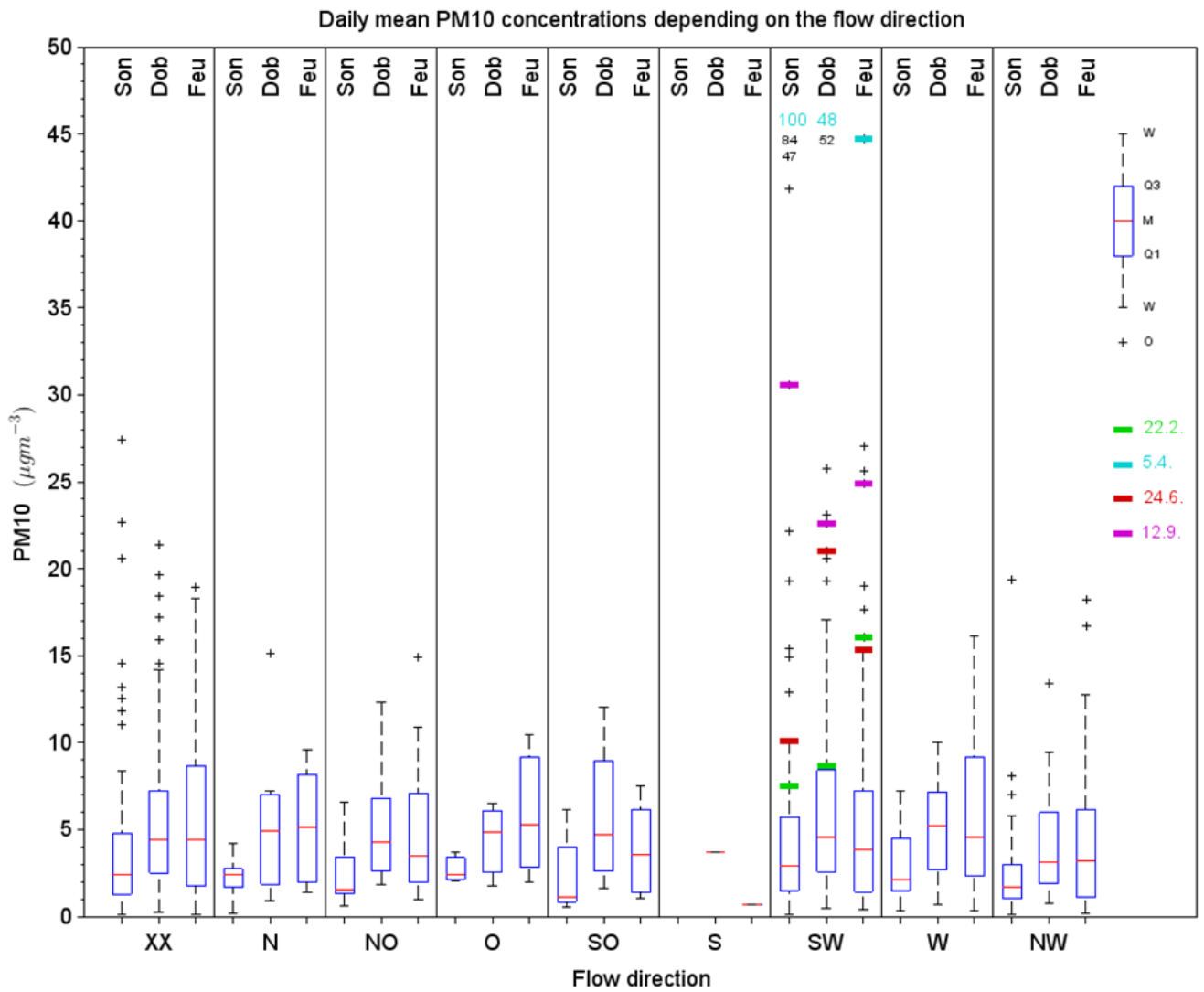

Fig. 2. Statistical analysis (boxplot) of daily mean $\mathrm{PM}_{10}$ concentrations at the mountain tops of Sonnblick (Son), Dobratsch (Dob) and Feuerkogel (Feu) between January 14, 2016 and December 31, 2016, separated according to the large-scale flow (Classification of Atmospheric Circulation Patterns representative for the Alpine area deduced from model output). $\mathrm{XX}$ represents all days when weak pressure gradients were prevailing and no dominant synoptic-scale flow direction is discernible. The bottom and top of the box depict the lower quartile (Q1) and upper quartile (Q3), the band inside the box is the median (M). The lines extending vertically from the boxes (whiskers) indicate the minimum and maximum values (except for outliers). Outliers $(\mathrm{O})$ are defined as any points larger than $\mathrm{Q} 3+1.5 \times \mathrm{IQR}$ or lower then $\mathrm{Q} 1-1.5 \times \mathrm{IQR}$, where IQR is the inter quartile range defined as IQR $=\mathrm{Q} 3-\mathrm{Q} 1$. Outlier values larger than $50 \mu \mathrm{g} \mathrm{m}^{-3} \mathrm{PM}_{10}$ are marked in colours and the respective day is given in the legend on the right side of the figure.

is used in the presented study, applying FLEXPART in backward mode in order to detect the source regions for the air which is probed by the instruments at the mountain sites during a particular measuring period (of typically 3 hours in length). The model results are presented as spatial distributions of the so called "source-receptor sensitivities (SRS)." The values of this model parameter can be interpreted as spatial information indicating those areas where a larger or smaller proportion of the air at the respective site came from.

In this study, FLEXPART is applied in backward mode based on model-level analyses from the European Centre for Medium Range Weather Forecast with $1^{\circ} \times 1^{\circ}$ resolution and 60 vertical layers. In contrast to Birmili et al. (2010), source-receptor sensitivity fields are evaluated for the lowest $2 \mathrm{~km}$ AGL. This setting is optimized for the application of Saharan dust transport detection. The layer between $0 \mathrm{~m}$ and $2000 \mathrm{~m} \mathrm{AGL}$ is considered in order to capture contributions from sources near the ground, dust uptake within the major part of the atmospheric boundary layer during daytime as well as elevated dust layers within the residual layer above the nocturnal boundary layer. Test runs revealed that SRS fields are similar from $0 \mathrm{~m}$ to $1500 \mathrm{~m}$ AGL or from $0 \mathrm{~m}$ to $2500 \mathrm{~m}$ AGL, but significantly change when near-ground levels are considered only as in Birmili et al. (2010). The results of these backward model runs in Fig. 9 indicate the origin of air masses which arrive at the mountain stations north, south and at the Alpine ridge within a 3-hour time interval.

\section{Chemical Weather Forecast}

WRF-Chem (Grell et al., 2005) is the Weather Research and Forecasting (WRF) model coupled with chemistry. This on-line coupled model simulates the emission, transport, mixing, and chemical transformation of trace gases and aerosols simultaneously with the meteorology. In the model set-up for this study, the direct (radiation), indirect (cloud, precipitation) and semi-direct (wind, temperature, humidity) feedbacks/effects between meteorology and air chemistry are included. WRF-Chem version 3.4.1 is applied with the PBL scheme developed by Yonsei University, the cloud microphysics scheme described by Morrison and 
Milbrandt (2015), NOAH land surface model (Niu et al., 2011) and the RRTMG scheme for long-wave and short wave radiation (Iacono, 2008). The RADM2 chemical mechanism (Stockwell et al., 1990) is used for gas phase chemistry. Biogenic emissions are considered by the MEGAN approach developed by Guenther et al. (2006). The latest anthropogenic emission inventories provided by the Austrian federal states are combined with emission data provided by TNO (Visschedijk et al., 2007) and EMEP (http://www.ceip.at/ceip).

Saharan dust is simulated in this study using the aerosol module including aqueous reactions MADE/SORGRAM (Schell et al., 2001) with dust emission option. In the WRF-Chem model output, the parameter DUSTcol is the sum of the vertical integral (up to $50 \mathrm{hPa}$ ) of the coarse soil derived aerosols and the coarse soil derived aerosols in clouds.

In the current study, the meteorological fields are based on ECMWF forecasts with $0.125^{\circ} \times 0.125^{\circ}$ horizontal resolution and 138 vertical layers. The episode has been simulated with WRF-Chem runs for 24 hours including a daily initialization of the meteorological fields. The horizontal resolution is $12 \mathrm{~km}$ for the area of Europe and North Africa (see model domain in Fig. 10). $\mathrm{PM}_{10}$ concentrations simulated with WRF-Chem are compared to observations, and model runs with and without modelled desert dust emissions are used to investigate the impact of Saharan dust transport on the $\mathrm{PM}_{10}$ concentrations in the Alpine region.

\section{RESULTS AND DISCUSSION}

This section starts with an overall analysis of the particle matter concentrations found at the mountain top stations in different flow regimes. It continues describing the evolution of PM mass concentrations during the Saharan dust episode and compares the measurements with observed aerosol profiles from nearby ceilometers. This is followed by a source region analysis based on FLEXPART backward runs. This observed data analysis is then contrasted with the forecast of the Saharan dust event based on WRF-Chem concentration fields. Finally, the forecast is evaluated comparing it with the aerosol measurements. In this way, a composite picture of this extraordinary Saharan dust event is achieved.

\section{Particle Matter at Mountain Tops in Different Flow Regimes}

In the following, the occurrence of events with increased PM concentrations at the three mountain top stations is investigated according to the prevailing synoptic conditions. Usually, pollution levels at mountain tops are quite low. Pollutants conveyed by long-range transport at higher levels or events with pollutants mixed from the valley floors to the mountain tops typically under convective conditions causing enhanced concentrations are therefore often clearly visible.

Analyses of predominant flow patterns for the year 2016 as well as on a long-term average from 2000 to 2016 reveal a predominance of south-westerly flows and weather patterns with weak winds. Hence, the statistical analysis of daily mean $\mathrm{PM}_{10}$ concentrations at mountain stations is most significant for these two large-scale flow patterns (Fig. 2). During south-westerly to south-easterly flows, $\mathrm{PM}_{10}$ concentrations on average tend to be slightly higher at Dobratsch, on the south side of the Alpine main crest than at Feuerkogel, on the north side of the Alps. Besides the impact of local sources (wood burning in villages), polluted air from industrial areas in the Po Valley is transported to the southern Alpine crest under southerly flow conditions while the northern Alpine crest is less affected in these cases.

On the other hand, $\mathrm{PM}_{10}$ concentrations tend to be higher at Feuerkogel, north of the Alps, than at Dobratsch, south of the Alps, during northerly flows as is seen from the upper whiskers and outliers in the columns of northwesterly, northerly and north-easterly flows (Fig. 2). In these cases, the northern Alpine crest is exposed to longrange transport from various industrial areas in Europe. However, it must be mentioned that except for southwesterly flows, sample sizes for weather patterns with weak winds and north-westerly flows are too small to achieve statistical representativeness. Thus, these dependencies of $\mathrm{PM}_{10}$ concentrations and distributions on flow patterns can only be evaluated qualitatively.

Four days with high daily $\mathrm{PM}_{10}$ concentrations at all three mountain sites are highlighted in color in Fig. 2. The on-line monitoring of mineral dust, which is performed at the Sonnblick, indicates the occurrence of dust events during those days. This monitoring follows the approach of Coen et al. (2004) and evaluates the wavelength dependence of the single scattering albedo (SSA) in the range from 450 to $635 \mathrm{~nm}$. The SSA is calculated via the scattering and absorption coefficients determined at the site. A detailed description of the index which is used to identify Saharan dust events from these measurements can be found in Schauer et al. (2016). The following analyses focus on the episode leading to the maximum daily mean $\mathrm{PM}_{10}$ concentrations observed at the Austrian mountain stations on April 5, 2016.

\section{Evolution of PM Mass Concentrations during the Episode}

In the following, the evolution of the PM concentrations at the three mountain tops during the period of investigation is described as revealed by the measurements. Fig. 3 depicts the temporal evolution of $\mathrm{PM}_{10}$ concentrations at Dobratsch, Feuerkogel and PM concentrations at Sonnblick for the Saharan dust episode from March 31, 2016 to April 7, 2016.

The temporal evolution of the PM concentrations at all three stations allows a rough separation of the event into three episodes. Episode 1 spanned from March 31 at 12:00 UTC to April 3 at 12:00 UTC, occurring almost simultaneously at the three stations, merely with different intensities. Episode 2 spanned from April 3 at 12:00 UTC to approximately April 5 at 00:00 UTC with a delay of the increase of PM mass at Dobratsch of about 12 hours 


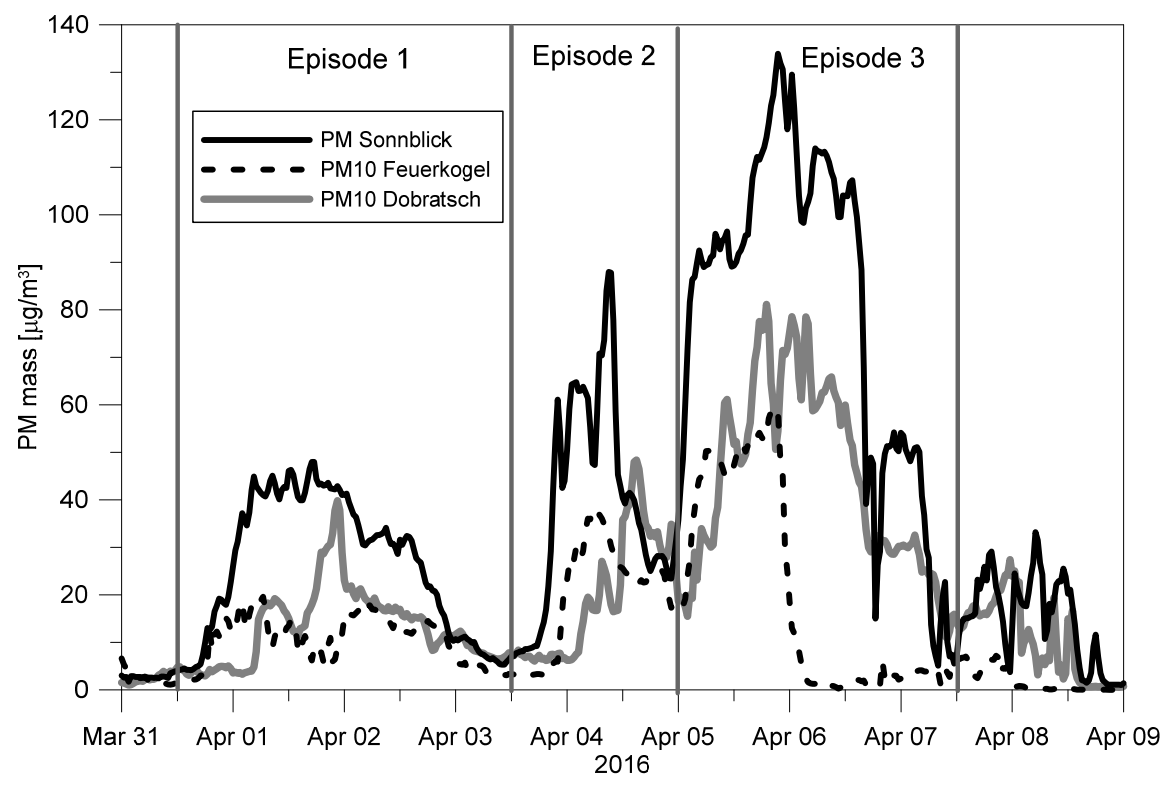

Fig. 3. Temporal evolution of PM concentrations at Sonnblick, Dobratsch and Feuerkogel from March 31, 2016, at 00:00 UTC to April 9, 2016, at 00:00 UTC. As explained in the text, no defined size cut can be reported for measurements at Sonnblick, whereas $\mathrm{PM}_{10}$ was determined at Dobratsch and Feuerkogel. Vertical grey lines indicate the three different episodes of this event.

compared to Sonnblick and Feuerkogel. Episode 3 started almost simultaneously at all three stations on April 5 at 00:00 UTC and lasted until April 6 at 00:00 UTC at Feuerkogel, but a few days longer, approximately until April 7 at 12:00 UTC, at Sonnblick and Dobratsch.

During all episodes, the highest PM concentrations are observed at Sonnblick. Saharan dust is transported at high elevations and over large distances via synoptic wind patterns. Thus, related PM concentrations are expected to be highest at high elevations, such as at Sonnblick (3.106 $\mathrm{m}$ a.s.l.). Due to vertical mixing, the long-range transported PM is mixed down, causing lower concentrations at lower elevations like at Feuerkogel (1.602 m a.s.l.) and Dobratsch (2.160 m a.s.1.).

The episodic evolution of PM mass can be explained via the prevailing synoptic wind pattern during that time. For Episode 1, a low pressure system over the Baleares transported the Saharan dust loaded air from the Western Sahara towards Europe. This low pressure system moved towards the Mediterranean, thereby weakening in intensity. Still Saharan dust was blown up into the air, but this time from the Eastern Sahara. Austria was under the influence of high pressure during that time, carrying the eroded dust towards Austria during Episode 2. Simultaneously a new low pressure system was formed over the Iberian Peninsula moving south towards Algeria, thereby intensifying. This low pressure system again mixed Western Saharan dust into the air which was then transported towards Austria during Episode 3.

The meteorological analysis of the investigated event reveals different Saharan dust source regions for the episodes. Various aerosol properties measured at Sonnblick were used to investigate potential differences in the aerosol composition, although no chemical analysis was performed for the different episodes.

First, the wavelength dependence of the SSA is used to identify long-range transport of mineral dust. Calculating the SSA exponent $\alpha S S A$, the change in sign of $\alpha S S A$ to negative values is used as an indication for mineral dust affecting the site. Regarding the whole episode, a median $\alpha S S A$ of -0.17 was obtained. This indicates that the majority of PM mass is represented by Saharan dust (Schauer et al., 2016). Median values of $\alpha \_S S A$ for the three sub-episodes are near to -0.19 (compare Fig. 4(a)). The wavelength dependence of the absorption coefficient is expressed by calculating the absorption exponent $\alpha \_A B S$. For the whole episode the median $\alpha_{-} A B S$ is 1.66 , while median values of the three sub-episodes are 1.54, 1.80 and 1.88, respectively (compare Fig. 4(b)). Fialho et al. (2006) reported an $\alpha \_A B S$ of 4.0 as typical for pure dust, whereas Schauer et al. (2016) used $\alpha A B S$ of 3.0 for Saharan dust and $\alpha A B S$ of 1.3 for wildfire. For the Saharan dust episode investigated here, $\alpha \_A B S$ values for Saharan dust were much lower and, regarding the observed range of $\alpha \_A B S$ values in literature, results for the sub-episodes are not markedly different. Minor differences can be related to differences in the source region, but also to the amount of Saharan dust within the aerosol influencing the coloring and hence the absorption properties of the particles.

Secondly, particle size distributions are used here to investigate potential differences in the different sub-episodes of the investigated Saharan dust event. The temporal evolution of the particle numbers of particles $>2.5 \mu \mathrm{m}$ (coarse particles) and the total particle number (denoted as CP-count) is displayed in Fig. 5 together with PM mass. PM mass is highly correlated to the number concentrations of coarse particles $\left(\mathrm{R}^{2}=0.997\right)$. In contrast to this, the CPcount showed little variation over all three sub-episodes 

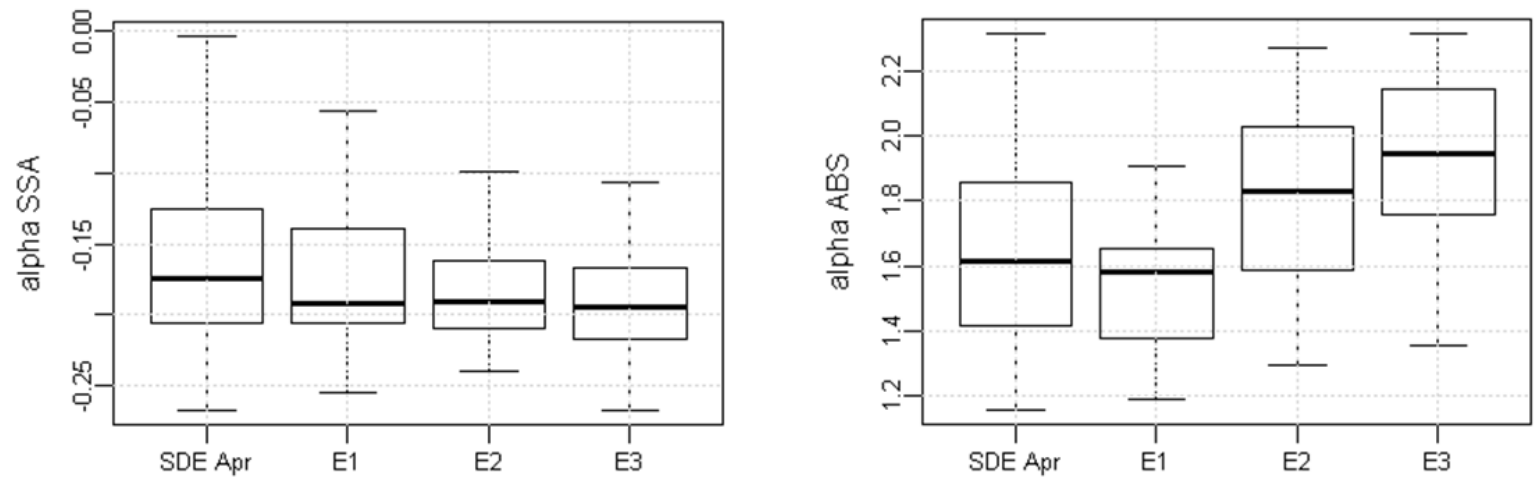

Fig. 4. Boxplot of (left) $\alpha S S A$ and (right) $\alpha A B S$ for the whole Saharan dust event at Sonnblick from March 31,2016 to April 7, 2016, as well as for the three episodes (E1 from March 31 at 12:00 UTC to April 3 at 11:30 UTC, E2 from April 3 at 12:00 UTC to April 4 at 23:30 UTC and E3 from April 5 at 00:00 UTC to April 7 at 12:00 UTC).

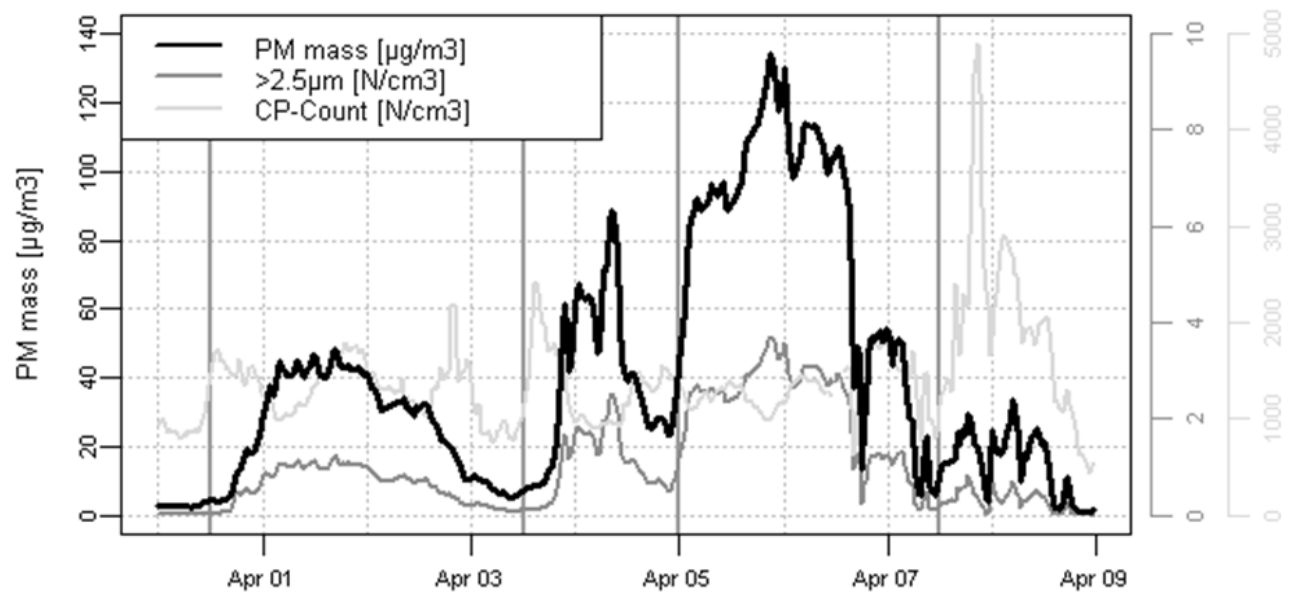

Fig. 5. $\mathrm{PM}$ mass in $\mu \mathrm{g} \mathrm{m}^{-3}$ (black) as well as particle numbers per $\mathrm{cm}^{3}$ of particles $>2.5 \mu \mathrm{m}$ optical diameter (dark grey) and condensation particle count (CP-count) representing the total particle number (light grey) of the Saharan dust event at Sonnblick from March 31, 2016, at 00:00 UTC to April 8, 2016, at 00:00 UTC. Vertical grey lines indicate the three different episodes of this event.

and no correlation with either PM mass or the number concentration of coarse particles $\left(\mathrm{R}^{2}=0.02\right.$ and $\mathrm{R}^{2}=0.01$, respectively).

If the particle number of the coarse fraction (optical diameter $>2.5 \mu \mathrm{m}$ ) is compared to the number of particles with an optical diameter $>0.3 \mu \mathrm{m}$ (compare Fig. 6), the contribution of coarse particles to number concentrations of particles $>0.3 \mu \mathrm{m}$ is almost similar for Episode 1 and 2 with mean values of $5.0 \%$ and $5.2 \%$, respectively, whereas for Episode 3 the ratio increased to a value of $6.7 \%$. Schauer et al. (2016) found values between 1.6 and $4.3 \%$ (representing the $10^{\text {th }}$ and $90^{\text {th }}$ percentile) for a Saharan dust episode in August 2013.

\section{Observed Aerosol Profiles}

Besides the in-situ measurements at the three mountain stations, the available remote-sensing data from ceilometers give further insight into the vertical distribution of aerosol density. The observations during the period of interest are presented in the following. The ceilometer at Nötsch is situated at the base of Dobratsch. Radstadt is situated in the valley directly north of the main Alpine chain. Salzburg is situated at the northern edge of the Eastern Alps comparable to the northern side of Feuerkogel.

The arrival of two dust clouds can be discerned from the backscatter plots of the three ceilometers in Figs. 7 and 8 . The first starts in the evening hours of March 31, the second just before midnight on April 3. The color coding in the figures is a measure of aerosol backscatter intensity, increasing from blue to full green. Dark blue areas indicate no data. Such areas are found most often above a cloud layer, shown by yellow and red lines near an aerosol layer height (black dotted lines). Red areas indicate rain. The first dust cloud on March 31 arrives almost at the same time at all three sites (Fig. 7). The enhancement of aerosols starts above $2 \mathrm{~km}$ AGL and propagates quite rapidly downwards. North of the main Alpine chain, clouds prevent the detection of the dust cloud on April 1 first at Salzburg (Fig. 7(a)), later at Radstadt (Fig. 7(b)). At Nötsch south of the Alpine chain, clouds are present at forenoon on April 2 (Fig. 7(c)). Especially from the plots at Radstadt, the impression of a persistent dust cloud above $3 \mathrm{~km}$ on April 2 


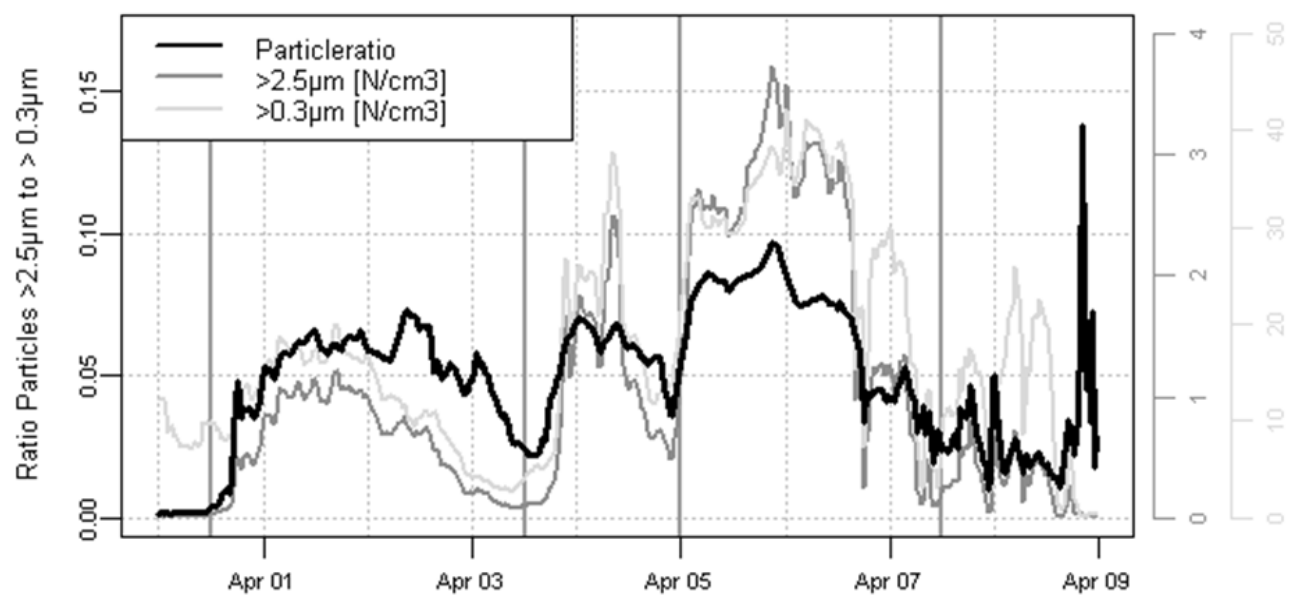

Fig. 6. Particle numbers per $\mathrm{cm}^{3}$ of particles $>2.5 \mu \mathrm{m}$ optical diameter (dark grey) and particles $>0.3 \mu \mathrm{m}$ optical diameter (light grey) as well as the ratio of these two (black) for the Saharan dust event at Sonnblick from March 31, 2016, at 00:00 UTC to April 8, 2016, at 00:00 UTC. Vertical grey lines indicate the three different episodes of this event.

and April 3 evolves (Fig. 7(b)). In the late evening on April 3 , the second, much stronger dust cloud arrives at ground level, first at Salzburg (Fig. 8(a)), later at Radstadt (Fig. 8(b)) and Nötsch (Fig. 8(c)). This is in good accordance with the contemporaneous increase of PM observed at the mountain stations at the beginning of Episode 2 (Fig. 3). In this episode, the dust cloud takes much more time to arrive at the surface, especially at Nötsch, where full mixing is observed on April 4 from about noon onwards only (grey line in Fig. 3). April 5 is the peak day of Episode 3 as well as of the whole event with uniform spread of dust throughout the boundary layer at all sites with a top around $3 \mathrm{~km}$ (Fig. 8). The visibility of the dust cloud ends first in Salzburg and later in Radstadt (Figs. 8(a) and 8(b)) due to a new cloud layer, with rain in the early morning on April 6. At the same time, the rapid decrease of PM concentrations is observed at Feuerkogel (dashed line in Fig. 3).

At the ceilometer sites Salzburg and Radstadt, cloud layers remain throughout the rest of the investigation period, preventing the detection of the Saharan dust cloud. At Nötsch, the dust layer is still visible throughout April 6 (Fig. 8(c)) and April 7 (not shown). A slight decay of aerosol backscatter intensity is visible in the ceilometer profiles within the mixed layer from the afternoon of April 6 onwards (Fig. 8(c)) indicating a gradual decrease of aerosol concentrations. The later finding is in good agreement with the gradual decrease of PM measurements at Sonnblick and Dobratsch in the second half of Episode 3 (black and grey lines in Fig. 3).

\section{Source Region Analysis}

The origin of the air masses which arrived at the Eastern Alps in the three phases of this event is investigated subsequently. The aim of this part of the investigation is to clarify whether dispersion modelling based on the large scale flow supports the hypothesis that the observed particle matter at the mountain sites during the respective period can be attributed to sources in North Africa. For this purpose, the areas where air masses arrive at Sonnblick during selected 3-hour intervals are identified by applying FLEXPART in backward mode. Fig. 9(a) depicts the integral of hourly fields of SRS for the layer between $0 \mathrm{~m}$ AGL and $2000 \mathrm{~m}$ AGL from the five previous days calculated for the time period April 1, 2016, from 09:00 UTC to 12:00 UTC when peak $\mathrm{PM}_{10}$ concentrations of Episode 1 were observed at Sonnblick. The numbers in the colored boxes (Fig. 9) give the proportion of air prevailing in the respective area within the previous five days. It has to be considered that air masses passing the blue box around Sonnblick in Fig. 9 partly originate from longrange transport. According to this model result, $22 \%$ of the air masses arriving at Sonnblick originated from the High Atlas and the Algerian Sahara (orange box in Fig. 9(a)). A contribution of $7 \%$ of the air masses originates in the eastern Sahara (green box in Fig. 9(a)).

The backwards transport modelling for the second period indicates a different result. On April 4, 20\% of the air masses can be retraced to the Eastern Sahara (green box in Fig. 9(b)), whereas only 2\% still originate from the Western Sahara (orange box in Fig. 9(b)).

For the third period, the FLEXPART model result in Fig. 9(c) renders that $24 \%$ of the air masses originate from the High Atlas and the Algerian Sahara (orange box) and $8 \%$ from the Eastern Sahara (green box). Thus, the source regions of desert dust varied significantly throughout this event although no clear difference could be detected in the chemical analysis of the aerosol measurements.

\section{Forecast of an Extraordinary Saharan Dust Event}

Measurements at mountain tops render valuable background concentration data for model evaluation. This is especially the case for long-range transport events as increased air pollution values preferably occur at higher level under these conditions. Therefore, the results of the operational WRF-Chem model runs which are conducted to forecast air quality in Austria are presented here and compared to the measurements in the following section. The ability to forecast long-range transport phenomena is of vital 


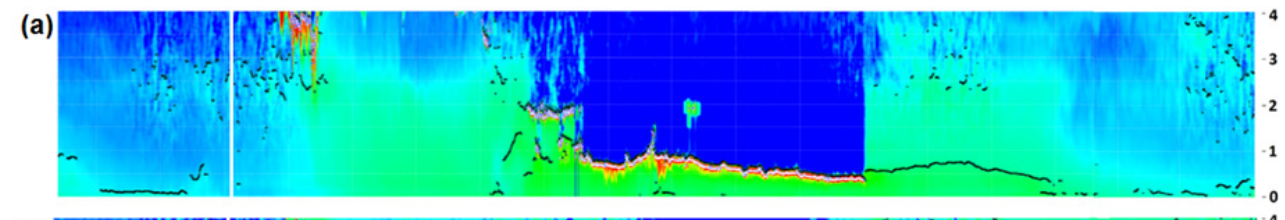

(b)

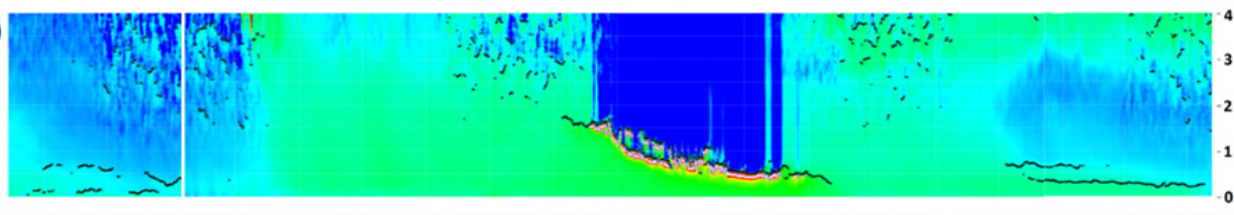

(c)
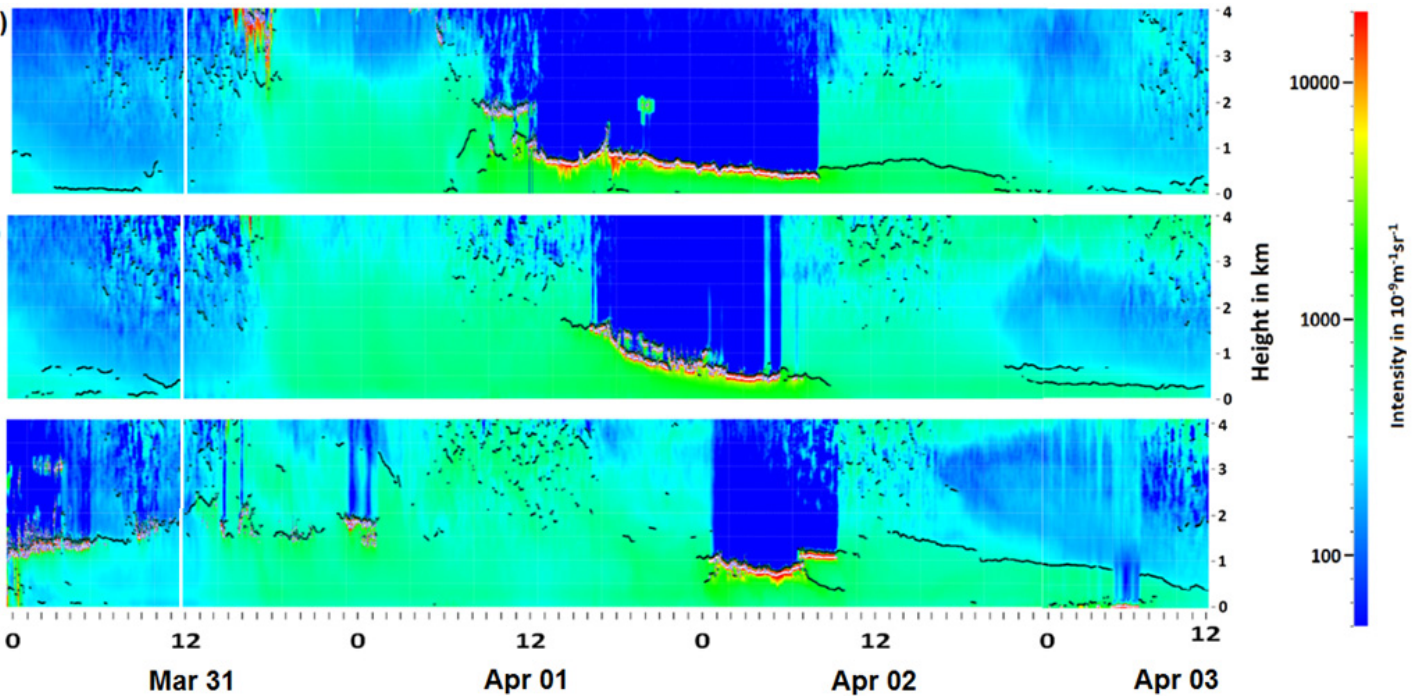

Fig. 7. Time-height cross sections of ceilometer aerosol backscatter intensity (a) at Salzburg, (b) at Radstadt, and (c) at Nötsch between March 31, 2016, at 00:00 UTC and April 3, 2016, at 12:00 UTC. The vertical white line indicates the beginning of the first episode of this event.
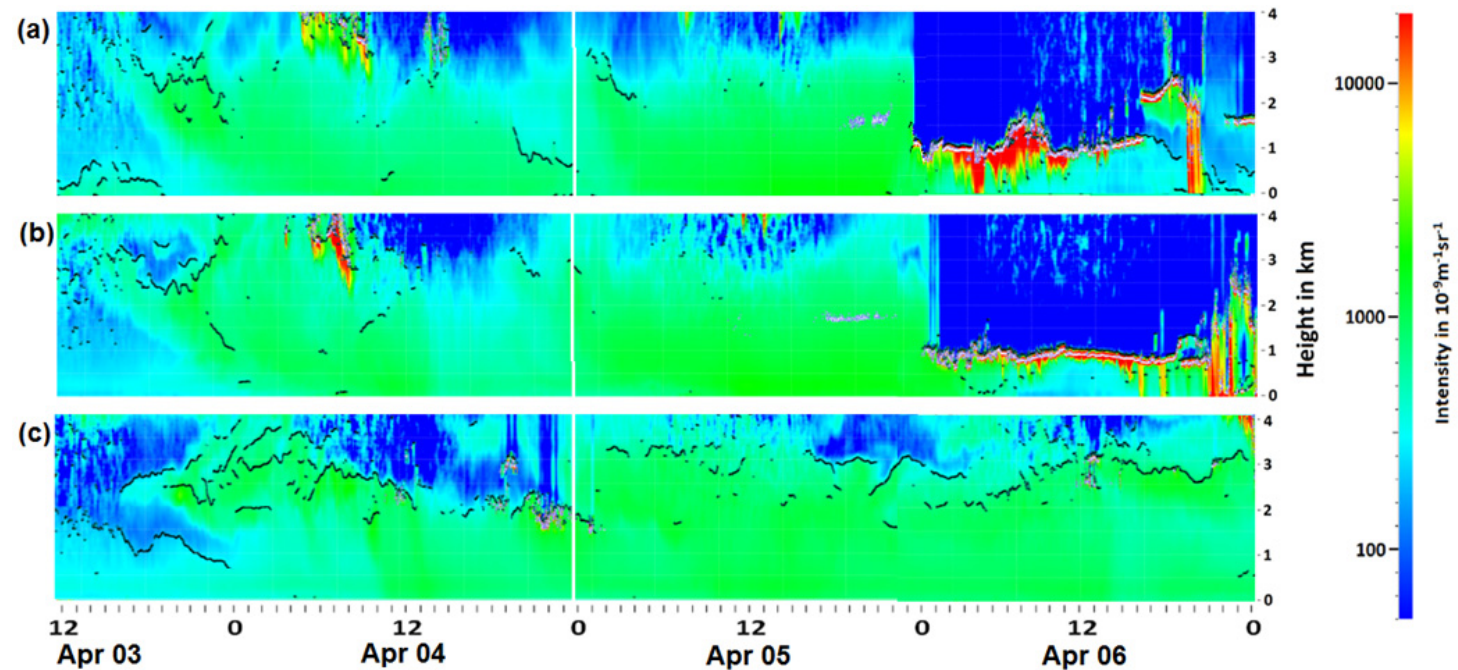

Fig. 8. Time-height cross sections of ceilometer aerosol backscatter intensity (a) at Salzburg, (b) at Radstadt, and (c) at Nötsch between April 3, 2016, at 12:00 UTC and April 7, 2016, at 00:00 UTC. The vertical white line indicates the end of the second/the beginning of the third episode of this event.

interest as there might be cases of serious health effects for the population which may require countermeasures, as with nuclear or industrial accidents, wildfires, pollen, etc. Here we investigate whether WRF-Chem is able to forecast the transport of the Saharan dust cloud from April 2016 towards Central Europe correctly.

According to the WRF-Chem model results, a dust cloud covered a large part of Central Europe already on April 1, 2016, propagating more to the east on April 2, 2016. The spatial distribution of dust concentration in the whole air column up to the top of the model domain $(50 \mathrm{hPa})$ on April 3, 2016, at 12:00 UTC and April 5, 2016, at 12:00 UTC calculated with WRF-Chem is shown in Figs 10(a) and $10(\mathrm{~b})$, respectively. According to the model results, the largest concentrations remained over the Algerian Saharan desert until April 4, 2016, most likely indicating sandstorm events in this area (see Fig. 10(a)). On April 5, 2016, the dust cloud is well seen in the WRF-Chem model output (Fig. 10(b)), the area with highest concentrations extending from the western Mediterranean Sea to the eastern Alpine area and covering major parts of Eastern Europe to the Black Sea. The dust cloud remains clearly visible in the Alpine area in the WRF-Chem model results until April 8, 2016.

Figs. 10(c) and 10(d) reveal the impact of desert dust emissions on the dust concentrations as forecasted by the model on April 3, 2016, at 12:00 UTC and on April 5, 2016, at 12:00 UTC, respectively. In the High Atlas region as well as on the Arabian Peninsula, red areas indicate regions where sandstorms are taking place. The red shaded region covering the western Mediterranean Sea and Central 


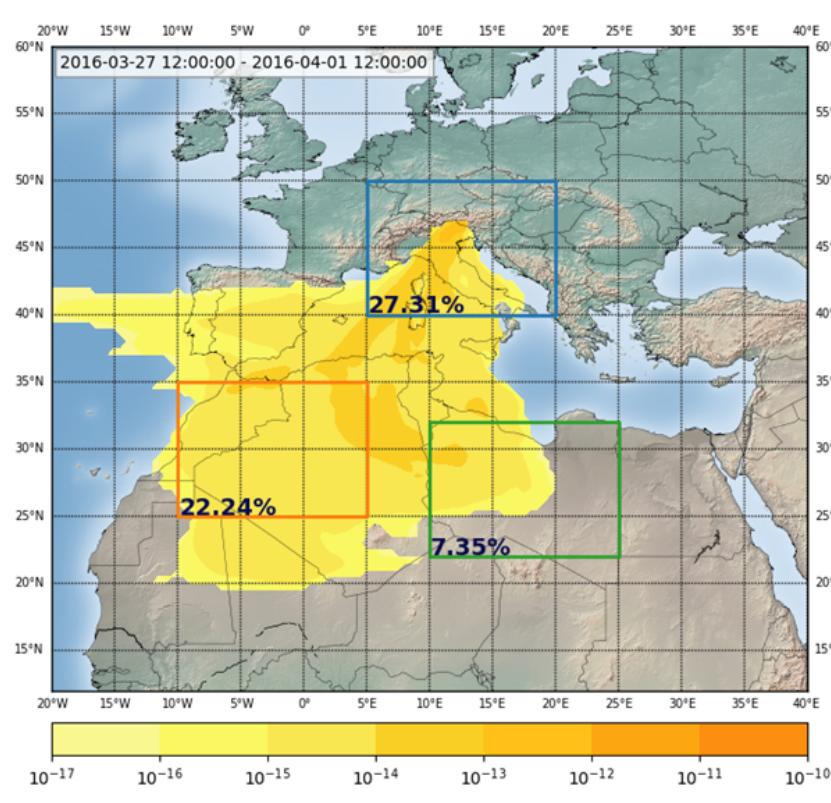

Collection Start: $2016-04-0109: 00$
Collection End: $2016-04-01$ 12:00

SRS-Field $\left[\mathrm{m}^{-3}\right]$

(a)

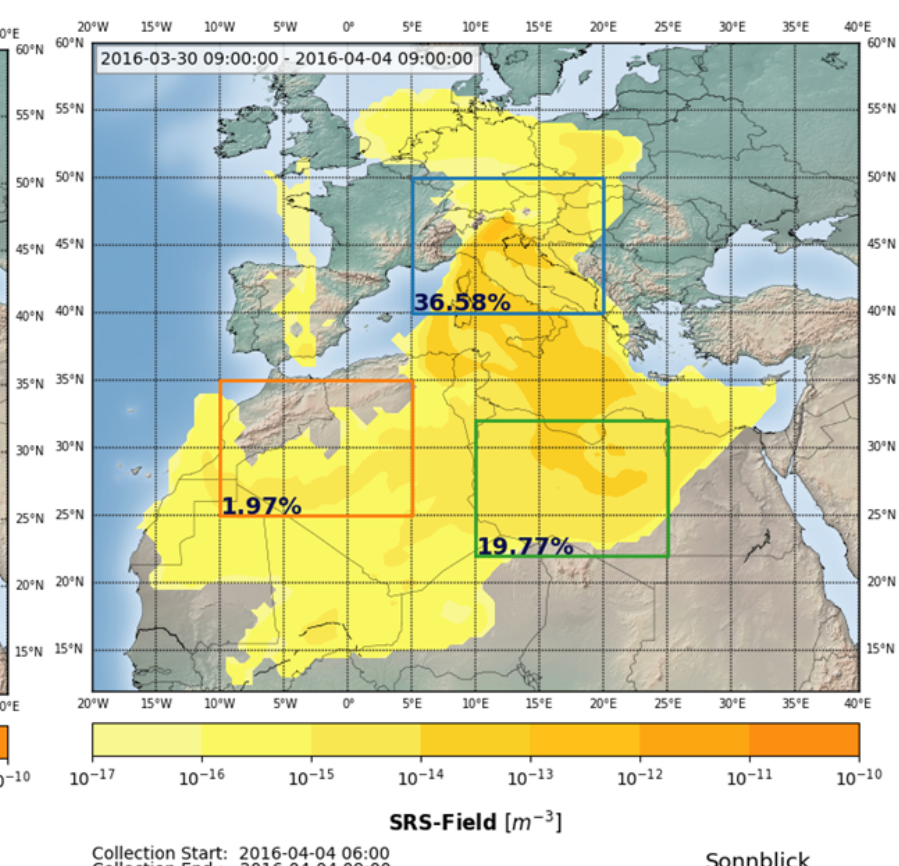

(b)

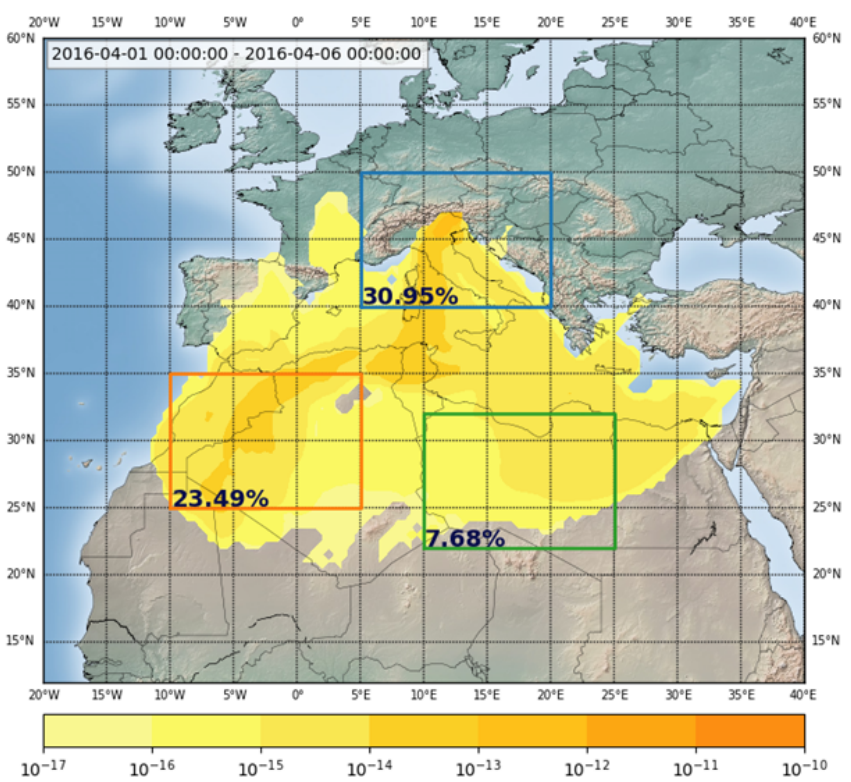

SRS-Field $\left[\mathrm{m}^{-3}\right]$

Collection Start: $2016-04-05$ 21:00
Collection End: $2016-04-06$ 00:00

Sonnblick

(c)

Fig. 9. Five-days integral source-receptor sensitivity fields of the lowest $2000 \mathrm{~m}$ above ground for the measurements at Sonnblick (a) on April 1, 2016, from 09:00 UTC to 12:00 UTC, (b) on April 4, 2016, from 06:00 UTC to 09:00 UTC, and (c) on April 5, 2016, from 21:00 UTC to April 6, 2016; percentages give proportion of air prevailing in Central and Southern Europe (blue box), in Western Sahara and High Atlas region (red box) and in Eastern Sahara (green box).

Europe on the other hand is clearly indicating the position of the Saharan dust cloud which has been transported here during the previous days.

\section{Forecast Evaluation}

In the following, the operational WRF-Chem model forecasts are evaluated in comparison to the aerosol measurements described in the previous sections. Mediumto long-range transport models in general may not resolve all the details of air pollution as revealed by in-situ observations at stations mainly because the latter may reflect the impact of local sources which are not revealed by the model emission data base.

According to the model results, up to $70 \%$ of the particle 


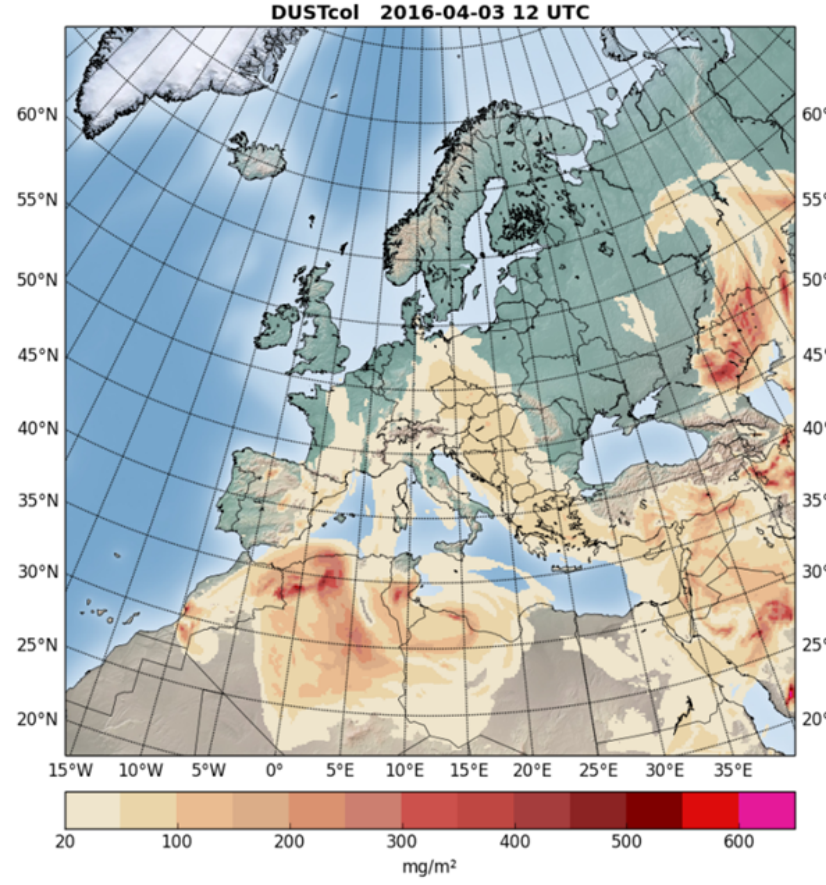

(a)

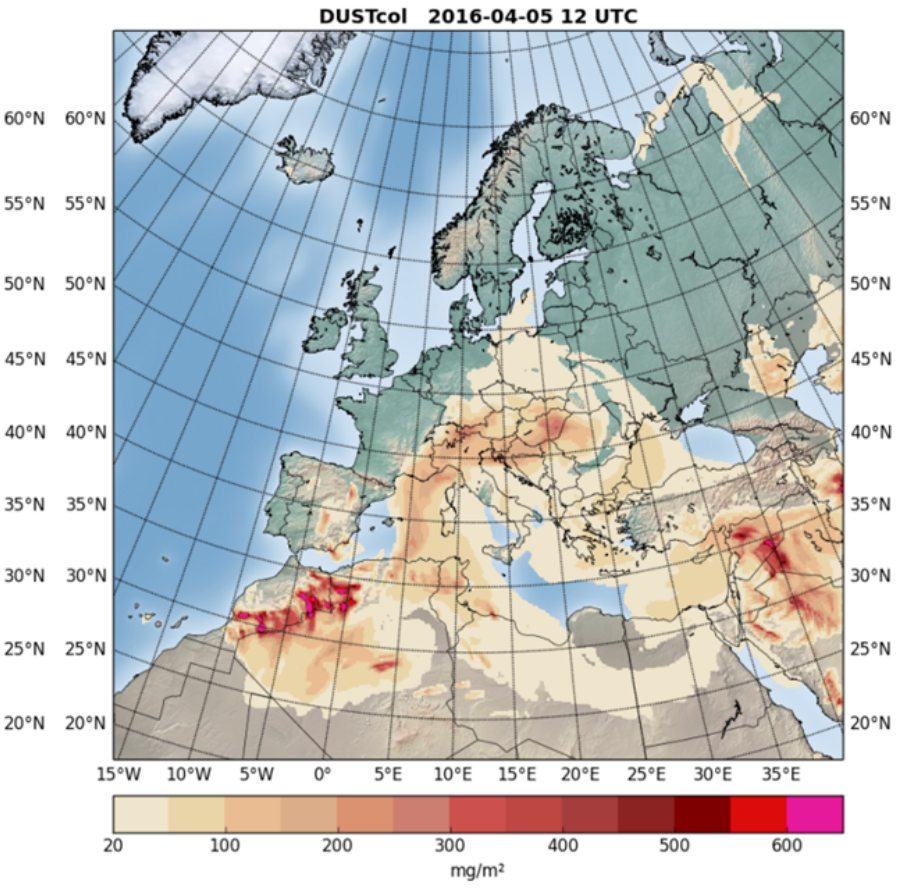

(b)

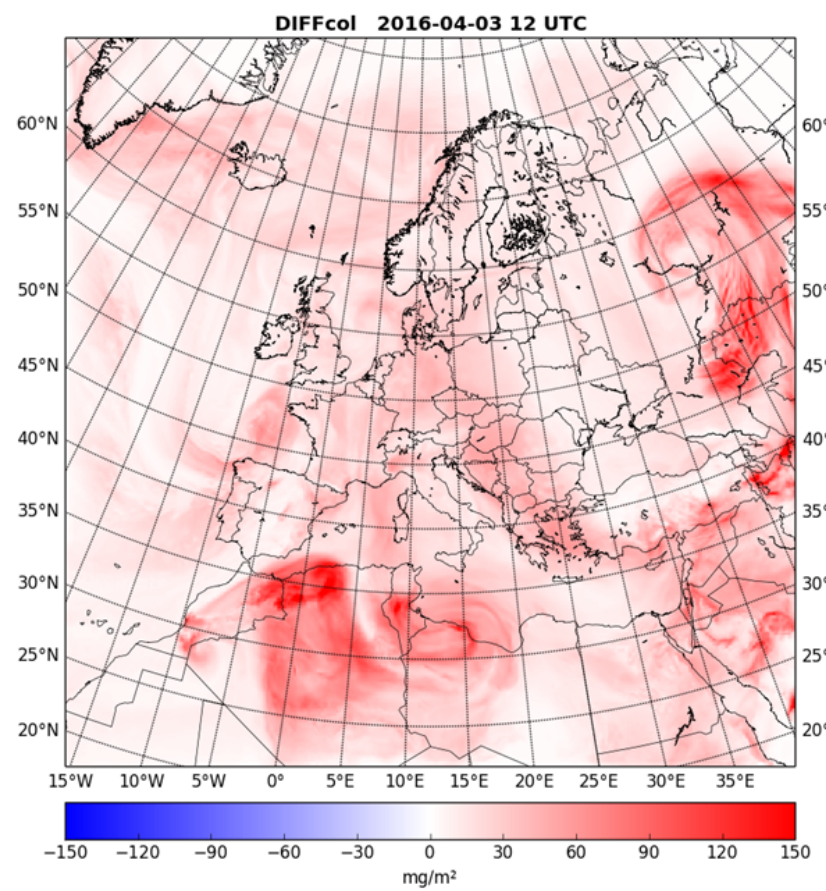

(c)

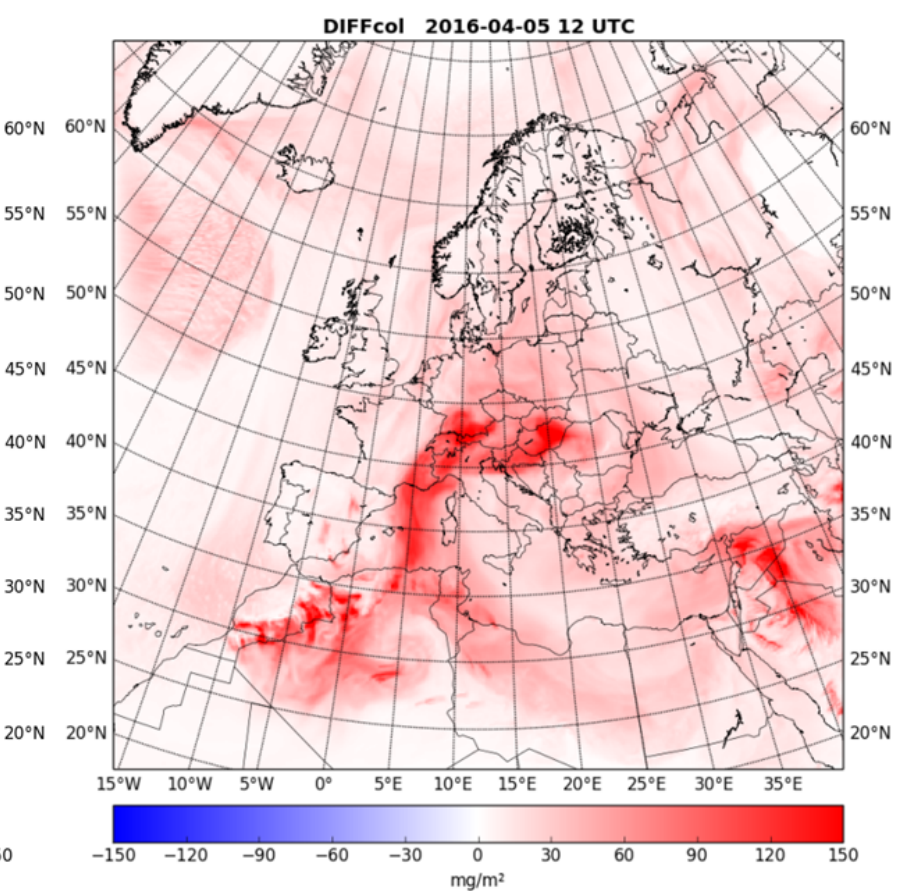

(d)

Fig. 10. Dust concentration over Europe $\left(\mathrm{mg} \mathrm{m}^{-2}\right)$ in the whole air column up to $50 \mathrm{hPa}$ simulated with WRF-Chem for (a) April 3, 2016, at 12:00 UTC and (b) April 5, 2016, at 12:00 UTC and the contribution to the dust concentrations due to desert dust for (c) April 3, 2016, at 12:00 UTC, and (d) April 5, 2016, at 12:00 UTC.

matter at the mountain tops can be traced back to dust emissions during the first six days of the event (dashed line in Fig. 11). The first PM peak at Sonnblick, on April 1, 2016, is well forecasted by the model regarding intensity as well as on-set and temporal evolution (Fig. 11(a)). The model forecasts for Dobratsch (Fig. 11(b)) and Feuerkogel (Fig. 11(c)) also are in good agreement with the observed arrival of the dust cloud during the first episode of the event. The largest discrepancies between the modeled and measured PM concentrations at all three sites are found in the results for April 3 and 4. In contrast to the measurements, the WRF-Chem results indicate a second increase of dust at Sonnblick and Feuerkogel in the beginning of April 3, 2016. The ceilometer profiles at Radstadt clearly reveal 
(a)

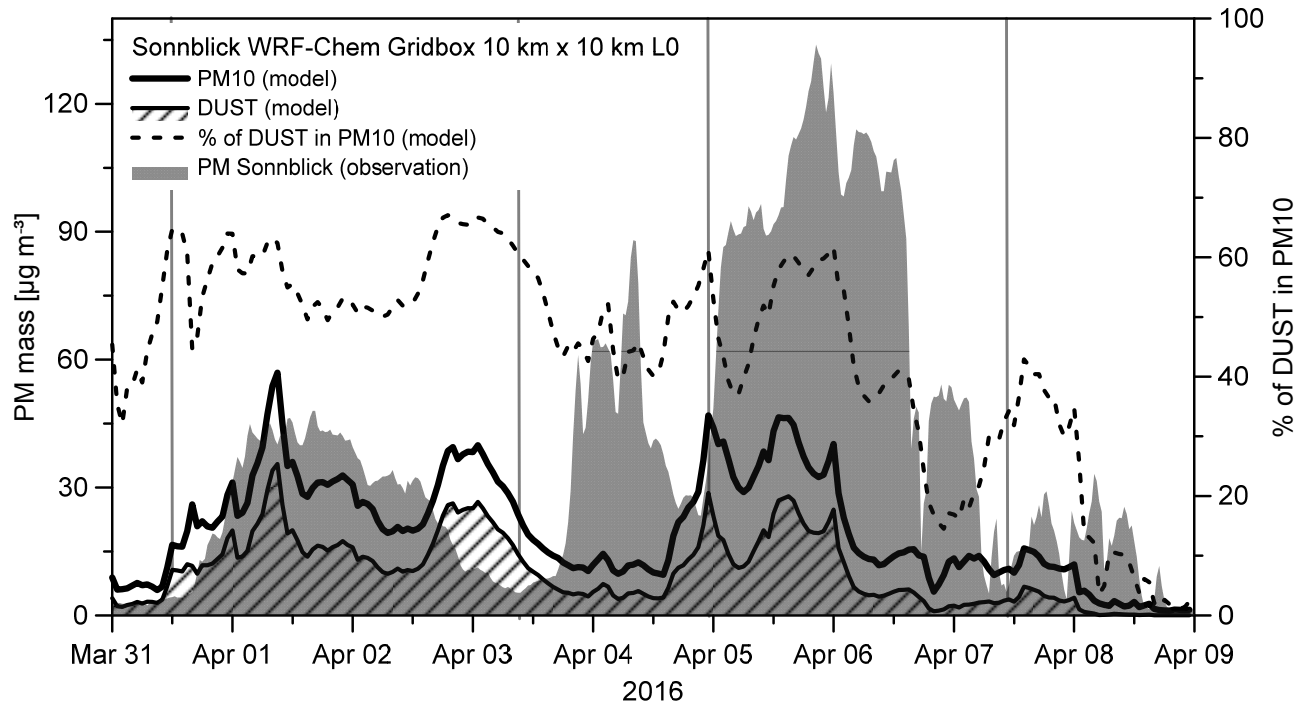

(b)

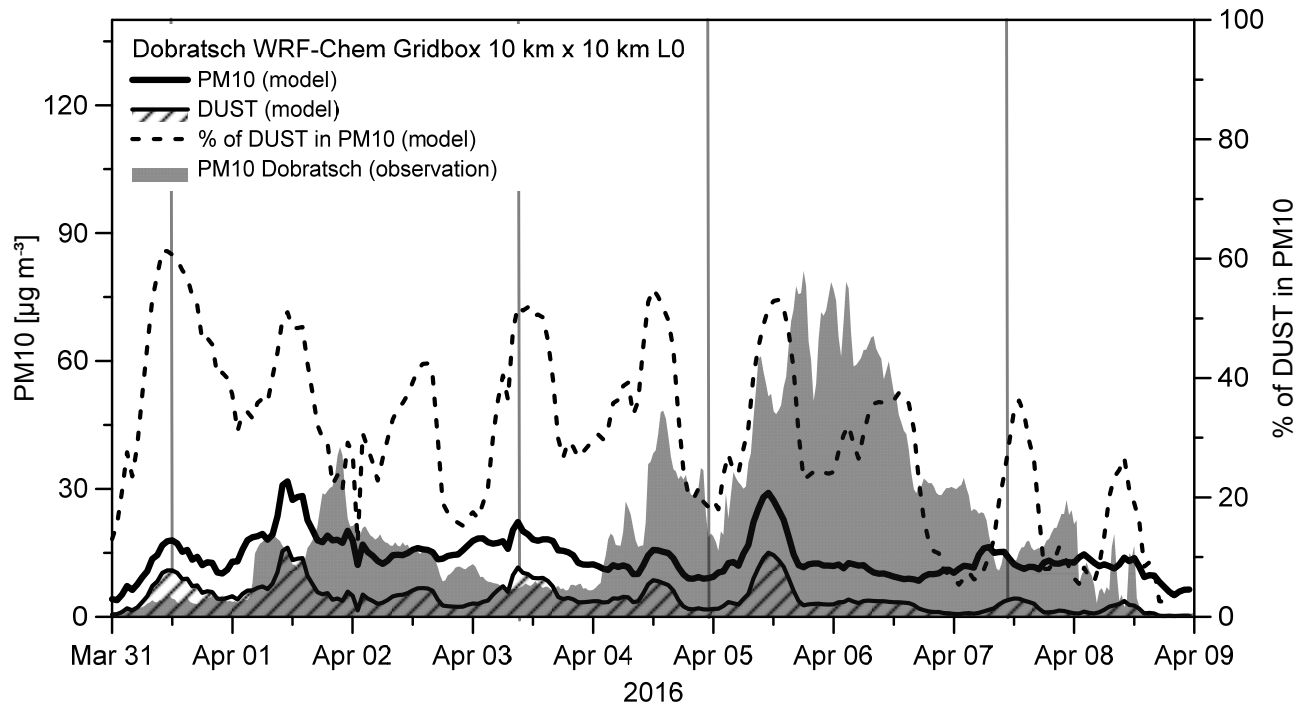

(c)

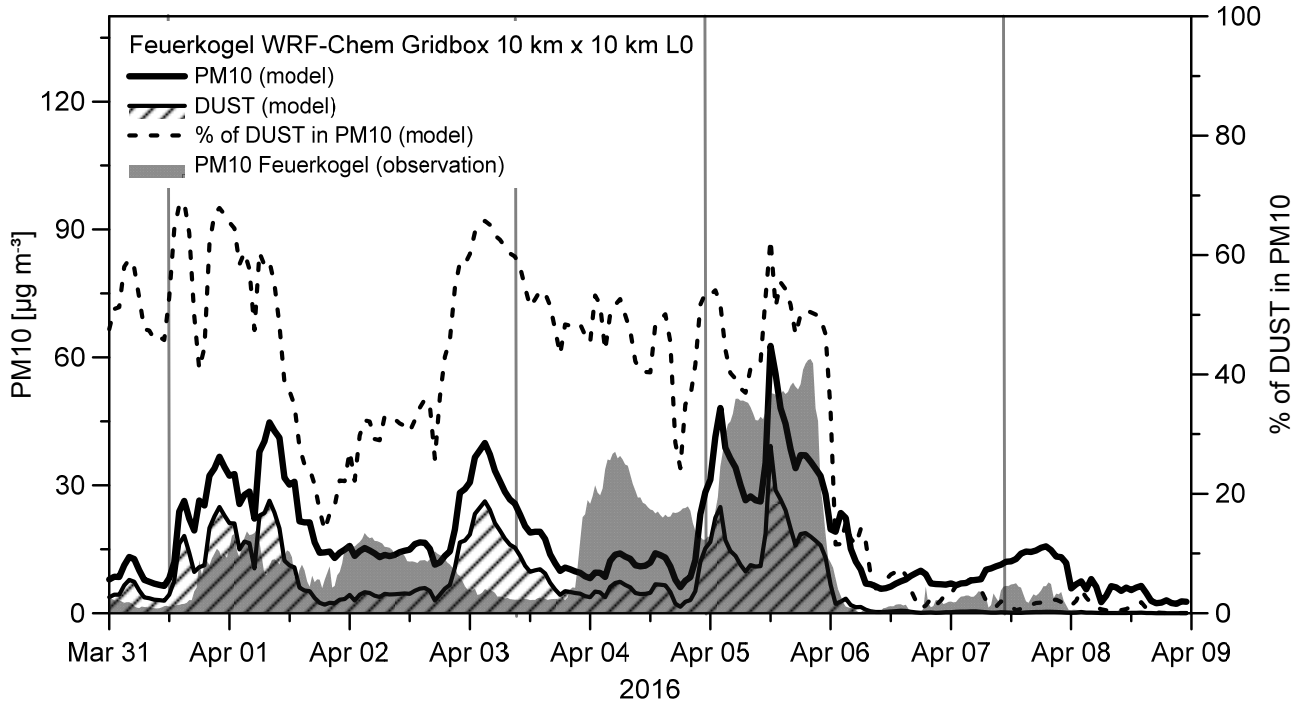

Fig. 11. Time-series of modelled PM concentrations (hourly values) within the lowest model layer within a $10 \mathrm{~km} \times 10 \mathrm{~km}$ grid box centred at the mountain sites from the operational WRF-Chem model run, simulated PM concentrations due to wind erosion only (DUST), the proportion of dust in the modelled PM concentrations and the measured concentrations (a) at Sonnblick, (b) at Dobratsch, and (c) at Feuerkogel, from March 31, 2016, at 00:00 UTC until April 9, 2016, at 00:00 UTC. 
that an aerosol layer was present above $3 \mathrm{~km}$ a.g.l. at the respective time (compare Figs. 11(a), 11(c), and 7(b)). Obviously this dust layer remains above the mountain tops and therefore has no impact on the in-situ aerosol measurements in the first half of April 3. The aerosol profiles observed by the ceilometers at Salzburg and Radstadt (Fig. 8) reveal a gradually descending aerosol layer during the afternoon of this day and the following night. At Dobratsch, a weak increase is visible in the model results on the same day around noon. On the other hand, an intense increase of PM is recorded at all three mountain stations at the beginning of April 4, 2018 (Fig. 11), while the concentration values forecasted with WRF-Chem remain low until the night to April 5.

No straightforward explanation for the differences between modelled and observed PM concentration on April 3 and April 4, 2016, can be given based on aerosol characterization. The simulated meteorological conditions on both days, dominated by a high pressure system over the Alpine area with large scale subsidence of dry upper level air, are in close agreement to the in-situ and the remote sensing observations. The only significant difference is that the model simulation indicates a small amount of precipitation at Sonnblick which is not confirmed by the observations. As this gives no explanation for the differences between modelled and measured PM concentrations on April 4, it is concluded that either the dust emissions due to wind erosion or the transport of the dust cloud leading to the observed increase of PM concentrations on April 4, 2016, was underestimated by the model.

A closer analysis of the model results for Dobratsch reveals that the simulated PM concentrations follow a daily cycle with increased values at noon and low values at night during the whole period of investigation (Fig. 11(b)). This is a clear indication that the model simulates boundary layer air enriched with particle matter from emission sources in the area reaching the site during day-time.

Finally, the time of the third and most intense arrival of dust at Sonnblick and Feuerkogel on April 5, 2016, is forecasted very well by WRF-Chem (Figs. 11(a) and 11(c)). The model also simulates successfully this dust event at the northern side of the Alpine ridge, at Feuerkogel (Fig. 11(c)) in terms of magnitude as well as the sudden decrease of PM concentrations caused by the change of air masses with a frontal passage taking place on April 6 at midnight. Still the PM concentrations are clearly underestimated at Sonnblick (Fig. 11(a)) and at Dobratsch (Fig. 11(b)). According to the ceilometer measurements the aerosol layer was most pronounced and persisted at the southern side of the Alpine ridge after the end of the investigated period (Fig. 8(c)). The percentage of dust due to wind erosion in the model results (dashed line in Fig. 11) decreases gradually at the end of the period. This is in good agreement with the PM concentrations observed at the mountain sites.

\section{CONCLUSIONS}

The measurements and modelling results presented in the previous sections - specifically, the large scale flow regime, as determined by classifying the weather circulation system from model output-reveal that transported dust clouds originating in North African sandstorms significantly contribute to peak concentrations of particulate matter over the Eastern Alps. In the statistical analysis of the PM measurements on three mountain tops in 2016 (Fig. 2), the highest daily mean concentrations were observed under south-westerly flow conditions. The maximum PM concentrations of the year at the three sites occurred in the first week of April. This event can be separated into three episodes, with waves of dust arriving at the mountain tops as depicted in Fig. 4.

The on-set of Saharan dust in the Alps during the first episode, the maximum PM peak during the third episode and the end of the dust event in April 2016 are, in general, accurately forecasted by the WRF-Chem model. The dust emissions in the Algerian Saharan desert due to stormy winds as well as the transport across the Mediterranean Sea to Central Europe are reproduced in the model reasonably well. The modelled and observed PM mass concentrations of the second episode differ significantly in amount as well as temporal evolution (Fig. 11). Sonnblick Observatory's on-line characterization of the aerosols offers no explanation for the differences between these episodes. Uncertainties in the estimation of the dust emission based on the forecasted surface wind speed in the desert area, deviations in the simulated regional flow fields and uncertainties in the representation of the atmospheric boundary layer, which is close to the mountain tops, in the model seem to be responsible for these discrepancies. The evolution of the aerosol profiles monitored by ceilometers during the event illustrates the complexity of the interacting processes, with descending layers of dust from higher levels mixing with the atmospheric boundary layer over the course of days (Figs 7-8). The results of the FLEXPART backward model runs shed light on the most dominant source regions of $\mathrm{PM}_{10}$ on the mountain tops, even allowing us to approximately quantify the proportion of air masses originating in a predefined area. Quantification based on the SRS fields has been performed for the first time in this study. This methodology will be further elaborated in order to support the general interpretation of air quality measurements.

The good agreement between the modelling results and the observations of the first two days as well as the successfully forecasted $\mathrm{PM}_{10}$ concentrations on the last day of the event show that the parameterisations and assumptions used in the operational WRF-Chem runs are appropriate to forecasting dust storm emission and transport as well as the deposition of particle matter at the mountain sites. Therefore, we estimate that up to a $70 \%$ contribution from Saharan dust to the observed PM concentrations during the event in April 2016, as simulated by WRF-Chem (Fig. 11), is plausible.

This case study demonstrates that our combination of measurements and analytical tools is a good basis for the interpretation of exceptional air pollution events caused by long-range transport. In general, peak episodes observed at 
background sites can be investigated by the proposed structured approach, which utilizes detailed analysis of the observational data and source area analysis by means of Lagrangian dispersion modelling, as well as meteorological and chemical modelling.

Finally, identifying long-range transported emissions is particularly relevant to evaluating increased PM concentrations, as dust imported from arid areas may be classified as "natural events" in the air quality measurements officially reported to the European Union and do not add to the number of daily mean threshold exceedances for $\mathrm{PM}_{10}$.

\section{ACKNOWLEDGMENTS}

The federal authorities of Austria are thanked for the air quality measurement data from the operational network as well from the mountain stations Dobratsch and Feuerkogel. Stefan Oitzl and Gerhard Heimburger are especially acknowledged for supporting this study. The aerosol measurements at Sonnblick are conducted in cooperation of the Central Institute for Meteorology and Geodynamics, the Environment Agency Austria, Land Salzburg and the Austrian Academy of Sciences (Climate and Air Quality Commission).

This study has been funded by the Austrian Ministry of Science and Research in the course of a development grant to ZAMG for the year 2016 as well as in the frame of the research project DUSTFALL financed by the Austrian Research Promotion Agency.

The investigations concerning the interpretation of ceilometer backscatter profiles and especially the mixing height estimation are significantly stimulated by the EU COST Action ES 1303 (TOPROF), dealing with groundbased remote sensing systems and the integration of their data into NWP models.

\section{REFERENCES}

Alpert, P. and Ganor, E. (2001). Sahara mineral dust measurements from TOMS: Comparison to surface observations over the Middle East for the extreme dust storm, March 14-17, 1998. J. Geophys. Res. 106: 18275-18286.

Ansmann, A., Bösenberg, J., Chaikovsky, A., Comerón, A., Eckhardt, S., Eixmann, R., Freudenthaler, V., Ginoux, P., Komguem, L., Linné, H., Márquez, M.Á.L., Matthias, V., Mattis, I., Mitev, V., Müller, D., Music, S., Nickovic, S., Pelon, J., Sauvage, L., Sobolewsky, P., Srivastava, M.K., Stohl, A., Torres, O., Vaughan, G., Wandinger, U. and Wiegner, M. (2003). Long-range transport of Saharan dust to northern Europe: The 11-16 October 2001 outbreak observed with EARLINET. $J$. Geophys. Res. 108: 4783.

Barnaba, F., Bolignano, A., Di Liberto, L., Morelli, M., Lucarelli, F., Nava, S., Perrino, C. and Canepari, S. (2017). Desert dust contribution to $\mathrm{PM}_{10}$ loads in Italy: Methods and recommendations addressing the relevant European Commission Guidelines in support to the Air
Quality Directive 2008/50. Atmos. Environ. 161: 288305.

Birmili, W., Göbel, T., Sonntag, A., Ries, L., Sohmer, R., Gilge, S., Levin, I. and Stohl, A. (2010). A case of transatlantic aerosol transport detected at the Schneefernerhaus Observatory $(2650 \mathrm{~m})$ on the northern edge of the Alps. Meteorol. Z. 19: 591-600.

Coen, C.M., Weingartner, E., Schaub, D., Hueglin, C., Corrigan, C., Schwikowski, M. and Baltensperger, U. (2003). Saharan dust events at the Jungfraujoch: Detection by wavelength dependence of the single scattering albedo and analysis of the events during the years 2001 and 2002. Atmos. Chem. Phys. Discuss. 3: 5547-5594.

Coen, C.M., Weingartner, E., Schaub, D., Hueglin, C., Corrigan, C., Henning, S., Schwikowski, M. and Baltensperger, U. (2004). Saharan Dust Events at the Jungfraujoch: Detection by wavelength dependence of the single scattering albedo and first climatology analysis. Atmos. Chem. Phys. 4: 2465-2480.

De Angelis, M. and Gaudichet, A. (1991). Saharan dust deposition over Mont Blanc (French Alps) during the last 30 years. Tellus B 43: 61-75.

Emeis, S., Jahn, C., Münkel, C., Münsterer, C. and Schäfer, K. (2007). Multiple atmospheric layering and mixing-layer height in the Inn valley observed by remote sensing. Meteorol. Z. 16: 415-424.

Fialho, P., Freitas, M.C., Barata, F., Vieira, B., Hansen, A.D.A. and Honrath, R.E. (2006). The Aethalometer calibration and determination of iron concentration in dust aerosols. J. Aerosol Sci. 37: 1497-1506.

Flaounas, E., Kotroni, V., Lagouvardos, K., Klose, M., Flamant, C. and Giannaros T.M. (2016). Assessing atmospheric dust modelling performance of WRF-Chem over the semi-arid and arid regions around the Mediterranean. Atmos. Chem. Phys. Discuss, doi: 10.5194/acp-2016-307.

Ginoux P., Prospero, J.M., Gill, T.E., Hsu, N.C. and Zhao, M. (2012). Global-scale attribution of anthropogenic and natural dust sources and their emission rates based on MODIS Deep Blue aerosol products. Rev. Geophys. 50: RG3005.

Grell, G.A., Peckham, S.E., Schmitz, R., McKeen, S.A., Frost, G., Skamarock, W.C. and Eder, B. (2005). Fully coupled on-line chemistry within the WRF model. Atmos. Environ. 39: 6957-6975.

Guenther, A., Karl, T., Harley, P., Wiedinmyer, C., Palmer, P.I. and Geron, C. (2006). Estimates of global terrestrial isoprene emissions using MEGAN (Model of Emissions of Gases and Aerosols from Nature). Atmos. Chem. Phys. 6: 3181-3210.

Iacono, M.J., Delamere, J.S., Mlawer, E.J., Shephard, M.W., Clough, S.A. and Collins, W.D. (2008). Radiative forcing by long-lived greenhouse gases: Calculations with the AER radiative transfer models. J. Geophys. Res. 113: D13103.

Lotteraner, C. and Piringer, M. (2016). Mixing-height time series from operational ceilometer aerosol-layer heights. Boundary Layer Meteorol. 161: 265-287.

Monks, P.S., Granier, C., Fuzzi, S., Stohl, A., Williams, M.L., 
Akimoto, H., Amann, M., Baklanov, A., Baltensperger, U., Bey, I., Blake, N., Blake, R.S., Carslaw, K., Cooper, O.R., Dentener, F., Fowler, D., Fragkou, E., Frost, G.J., Generoso, S., Ginoux, P., Grewe, V., Guenther, A., Hansson, H.C., Henne, S., Hjorth, J., Hofzumahaus, A., Huntrieser, H., Isaksen, I.S.A., Jenkin, M.E., Kaiser, J., Kanakidou, M., Klimont, Z., Kulmala, M., Laj, P., Lawrence, M.G., Lee, J.D., Liousse, C., Maione, M., McFiggans, G., Metzger, A., Mieville, A., Moussiopoulos, N., Orlando, J.J., O'Dowd, C.D., Palmer, P.I., Parrish, D.D., Petzold, A., Platt, U., Pöschl, U., Prévôt, A.S.H., Reeves, C.E., Reimann, S., Rudich, Y., Sellegri, K., Steinbrecher, R., Simpson, D., ten Brink, H., Theloke, J., van der Werf, G.R., Vautard, R., Vestreng, V., Vlachokostas, C. and von Glasow, R. (2009). Atmospheric composition change - global and regional air quality. Atmos. Environ. 43: 5268-5350.

Morrison, H. and Milbrandt, J.A. (2015). Parameterization of cloud microphysics based on the prediction of bulk ice particle properties. Part I: scheme description and idealized tests. J. Atmos. Sci. 72: 287-311.

Nabavi, S.O., Haimberger, L. and Samimi, C. (2017). Sensitivity of WRF-Chem predictions to dust source function specification in West Asia. Aeolian Res. 24: 115-131.

Niu, G.Y., Yang, Z.L., Mitchell, K.E., Chen, F., Ek, M.B., Barlage, M., Kumar, A., Manning, K., Niyogi, D., Rosero, E., Tewari, M. and Xia, Y. (2011). The community Noah land surface model with multiparameterization options (Noah-MP): 1. Model description and evaluation with local-scale measurements. J. Geophys. Res. 116: D12109.

Pey, J., Querol, X., Alastuey, A., Forastiere, F. and Stafoggia, M. (2013). African dust outbreaks over the Mediterranean Basin during 2001-2011: $\mathrm{PM}_{10}$ concentrations, phenomenology and trends, and its relation with synoptic and mesoscale meteorology. Atmos. Chem. Phys. 13: 1395-1410.

Prospero, J.M. and Mayol-Bracero, O.L. (2013). Understanding the transport and impact of african dust on the Caribbean Basin. Bull. Am. Meteorol. Soc. 94: 1329-1337.

Querol, X., Pey, J., Pandolfi, M., Alastuey, A., Cusack, M., Pérez, N., Moreno, T., Viana, M., Mihalopoulos, N., Kallos, G. and Kleanthous, S. (2009). African dust contributions to mean ambient $\mathrm{PM}_{10}$ mass-levels across the Mediterranean Basin. Atmos. Environ. 43: 42664277

Rizza, U., Barnaba F., Miglietta, M.M., Mangia, C., Di Liberto, L., Dionisi, D., Costabile, F., Grasso, F. and Gobbi, G.P. (2017). WRF-Chem model simulations of a dust outbreak over the central Mediterranean and comparison with multi-sensor desert dust observations. Atmos. Chem. Phys. 17: 93-115.

Salvador, P., Astinano, B., Molero, F., Viana, M., Pey, J., Alastuey, A. and Querol, X. (2011). African dust contribution to ambient aerosol levels across central Spain: Characterization of long-range transport episodes of desert dust. Atmos. Res. 127: 117-129.

Salvador, P., Alonso-Pérez, S., Pey, J., Artíñano, B., de Bustos, J.J., Alastuey, A. and Querol, X. (2014). African dust outbreaks over the western Mediterranean Basin: 11-year characterization of atmospheric circulation patterns and dust source areas. Atmos. Chem. Phys. 14: 6759-6775.

Schauer, G., Kasper-Giebl, A. and Močnik, G. (2016). Increased PM concentrations during a combined wildfire and Saharan dust event observed at high-altitude Sonnblick Observatory, Austria. Aerosol Air Qual. Res. 16: 542554.

Schell, B., Ackermann, I. J., Hass, H., Binkowski, F.S. and Ebel, A. (2001). Modeling the formation of secondary organic aerosol within a comprehensive air quality model system. J. Geophys. Res. 106: 28275-2829.

Schepanski, K., Mallet, M., Heinold, B. and Ulrich, M. (2016). North African dust transport toward the western Mediterranean basin: Atmospheric controls on dust source activation and transport pathways during JuneJuly 2013. Atmos. Chem. Phys. 16: 14147-14168.

Seibert, P. and Frank, A. (2004). Source-receptor matrix calculation with a Lagrangian particle dispersion model in backward mode. Atmos. Chem. Phys. 4: 51-63.

Sodemann, H., Palmer, A.S., Schwierz, C., Schwikowski, M. and Wernli, H. (2006). The transport history of two Saharan dust events archived in an Alpine ice core. Atmos. Chem. Phys. 6: 667-688.

Stockwell, W.R., Middleton, P., Chang, J.S. and Tang, X.Y. (1990). The 2nd generation regional acid deposition model chemical mechanism for regional air-quality modeling. J. Geophys. Res. 95: 16343-16367.

Stohl, A., Eckhardt, S., Forster, C., James, P., Spichtinger, N. and Seibert, P. (2002). A replacement for simple back trajectory calculations in the interpretation of atmospheric trace substance measurements. Atmos. Environ. 36: 4635-4648.

Todd, M.C. and Cavazos-Guerra, C. (2016). Dust aerosol emission over the Sahara during summertime from Cloud-Aerosol Lidar with Orthogonal Polarization (CALIOP) observations. Atmos. Environ. 128: 147-157.

Visschedijk, A.J.H., Zandveld, P.Y.J. and Denier van der Gon, H.A.C. (2007). A high resolution gridded European emission database for the EU integrate project GEMS, TNO-report 2007-A-R0233/B.

Wagner, P. and Schäfer, K. (2015). Influence of mixing layer height on air pollutant concentrations in an urban street canyon. Urban Clim. 22: 64-79.

Received for review, March 30, 2018 Revised, November 13, 2018 Accepted, December 3, 2018 